\title{
AN-WOT model for designation and analysis of sustainable development strategies in Jam Abroud village
}

\author{
Shaho karami ${ }^{1}$, Maryam Larijani ${ }^{2}$, Hatef Marefat ${ }^{3}$ \\ ${ }^{1}$ Phd Student in Environmental education, Payame Noor University, Tehran, IRAN \\ ${ }^{2}$ Department of Environmental education, Payame Noor University, Tehran, IRAN \\ ${ }^{3}$ Msc Student in Environmental Engineering, University of Tehran, Tehran, IRAN
}

\section{Email address:}

Karami.sh@ut.ac.ir(sh. karami), larijani.research@yahoo.com(M. larijani), Hatef_Marefat@yahoo.com(H. Marefat)

\section{To cite this article:}

Shaho karami, Maryam Larijani, Hatef Marefat. AN-WOT Model for Designation and Analysis of Sustainable Development Strategies in Abroud Village. International Journal of Environmental Monitoring and Analysis. Vol. 1, No. 6, 2013, pp. 288-295.

doi: $10.11648 /$ j.ijema.20130106.13

\begin{abstract}
Establishment of sustainable development needs to develop new techniques. Which they can develop strategies and solutions to be applied strategies. One of the tools that help managers and planners to develop these strategies, that is using a SWOT analysis. In this study, by making use of the analytical network method, strengths and weaknesses due to internal factors and opportunities and threats caused by external factors were identified. Based on the findings, relevant strategies for the sustainable development of the Jam Abroud village and the executive programs needed for their implementation were designed. These strategies are limited for operational programs and priority. At this straight by using of Analytic Network process, which is one of multi action methods for deciding the strategies were graded. In the final the graded programs for doing the action programs in a period of ten years, with assigning the elements of responsible of these programmers was given. Results show that although the presented offensive patterns ranked best among strategies, followed by conservative, competitive and defensive patterns, but it was found that the use of a combination of the above-mentioned patterns and strategies with attention to their rankings provides the best opportunity to establish sustainable development in Jam Abroud vill.
\end{abstract}

Keywords: Environment, Social Capital, Manmade Capital, Preservative Pattern, Super Decision

\section{Introduction}

With the growth of knowledge and technology and the beginning of agriculture and domesticating the animals, human supply his needs which usually is connected with the environment. The human has made some changing on the ecosystem of the earth in comparison with the other animals.

With the growth of industry and blooming of it the same as industrial revolution, many changing has been done by the human in the ecosystem. However, in many parts of the world the ecosystem has been destroyed by the human. In other hand, the capacity of earth for supporting humans that determine with the natural limits human select in relation to economic, environment, culture and population is completely limit (Qrkhlo and Hoseini, 2006). So some opinions and actions for correcting the relation between human and environment has been done, that it caused the forming of sustainable development.

In 1987, world's commission to environment and development was introduced. This report by the name of "our common future" presented some states and original rules for arriving sustainable development for developing countries. The version of sustainable development for the first time as usual was stated in this report (Hanff et al, 2011) and in the Rio international conference was approved (lui et al. 2009). The most acceptable define from sustainable development, is define that was stated in Brantland report. Depend on this report; the growth of sustainable development depends on human needs and without making any damage to needs of new generation (mori \&christodulou, 2011). Meaning the sustainable development is a long time model development (Ivanovic et al, 2009). In the attitude of sustainable development we try to preventing from damage to the environment, destroying the ecosystem, agnostic, pollution, high population, and decreasing the quality of living. for humans in reality the complete sustainable conditions is prepared, when a total sustainable of environmental with equal aim of ecological, sustainable in economy, social sustainable with the aim of social justice 
and sustainable frame for sustainable aim of morphological be fixed (pourjafar, 2010).

In the other word, sustainable development is joining of bio ecosystem and social with economic subjects (Bio environment and society). Such developing is against with unsustainable growth economic and states this reality that, the kind of living is equal with some hazards (khatoon abadi, 2005). If we consider the three elements of sustainable development (social, economy and environment) the results will be more accurate as it has been shown (Figure2). Nevertheless the Figure (1) shows undesirable developments, that it is not very good, because the components of sustainable development are not in equal with each other (Enaati, 2007).

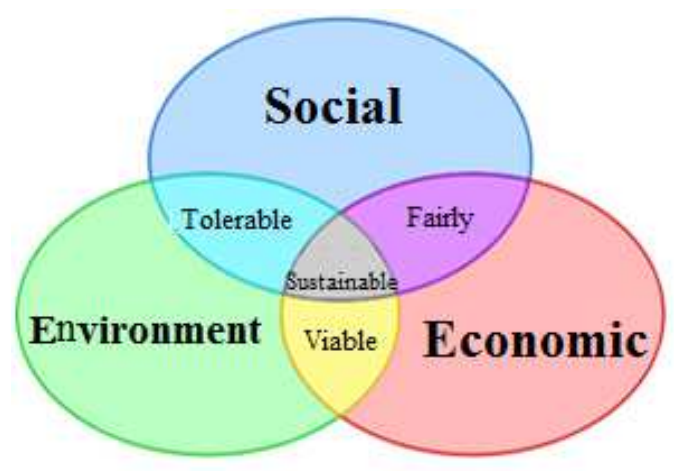

Figure 1. Stability of undesirable (Enayati, 2009)

The situation of components for sustainable development in different parts of a country is different (karakosta et al, 2009). The aim of this research is designation and analysis the strategies of sustainable development, and reducing the existing problems and it shows the sides of development (Rafieian et al, 2007).

\section{Materials and Method}

\subsection{Study Area}

The village of Jamabroud with two villages Tarood and Abrshive are located in the central Damavand city in the province of Tehran. The Damavand city is surrounded from north with Amoal city of Mazandaran province, from north east with Shemiranat city of Tehran province, and from east with Tehran, from south with Garmsar from Semnan province and from west with Firozkooh city from province of Tehran (Figure3).

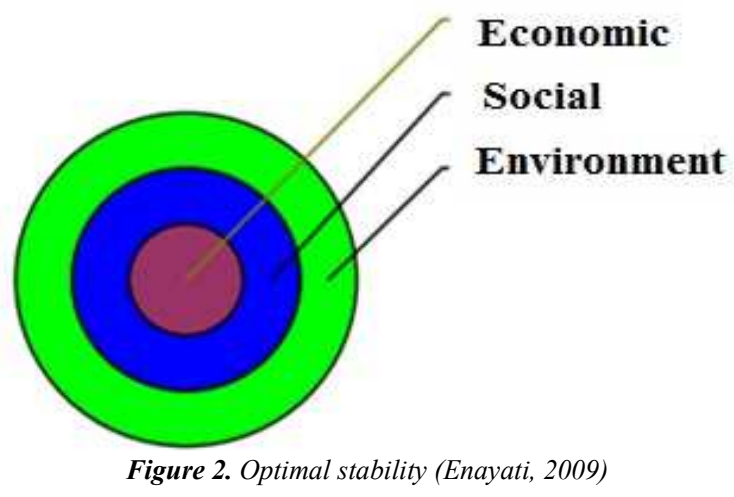

The state of Damavand includes six cities namely Damavand, Abali, Absard, Sarbandan, Mara and two countries (Markazi, Roadehen) and five villages (country ministry, 2011). The village Jamabroud with areas about 41468.8 hectare and population about 17.676 (static organization, 2012) is located in the south of Damavand and Absard is the center of it.

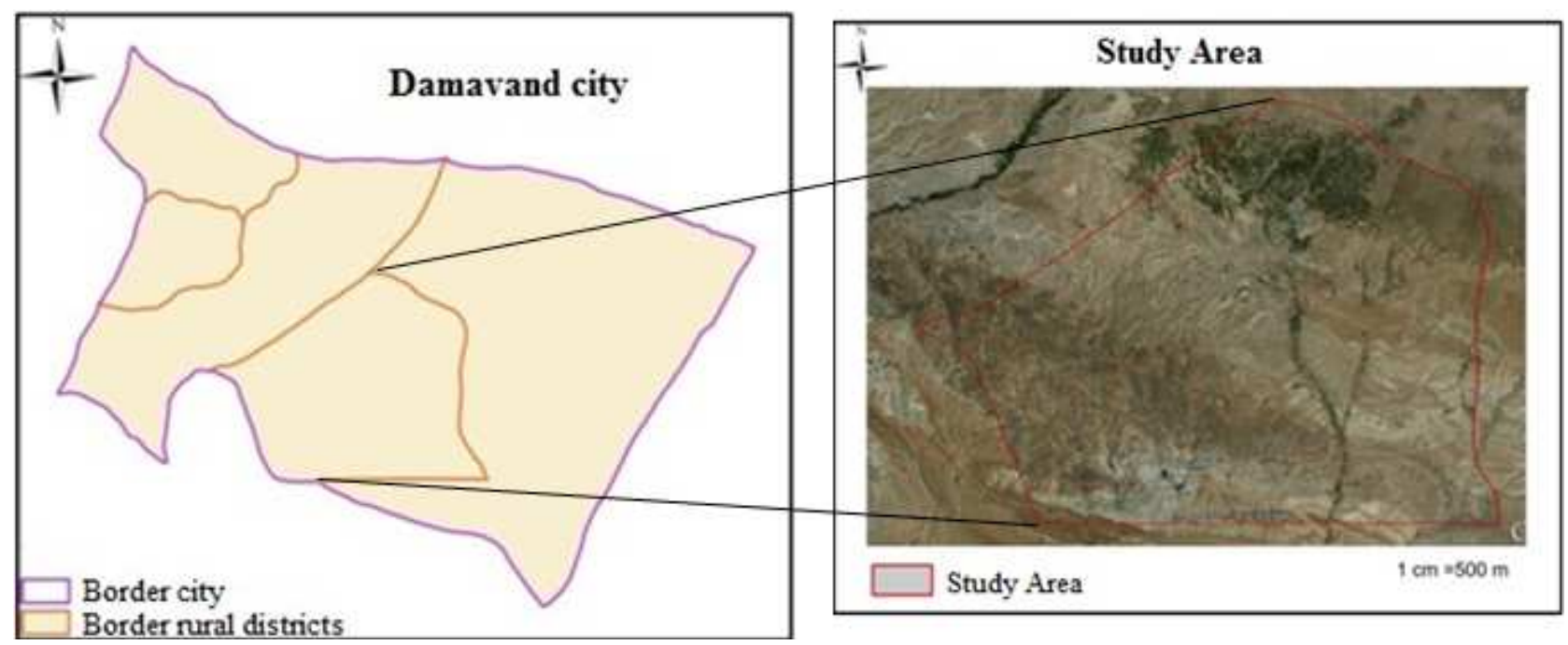

Figure 3. Location of the study area

It should be mentioned that the distribution of the people at this village are different and the society has different of wealth. However based on the Figure 4, it is possible to state each division of social capital in connection with sustainable extension components (economy, society and environmental) (Ziai and Mohammad Alipour, 2007). 


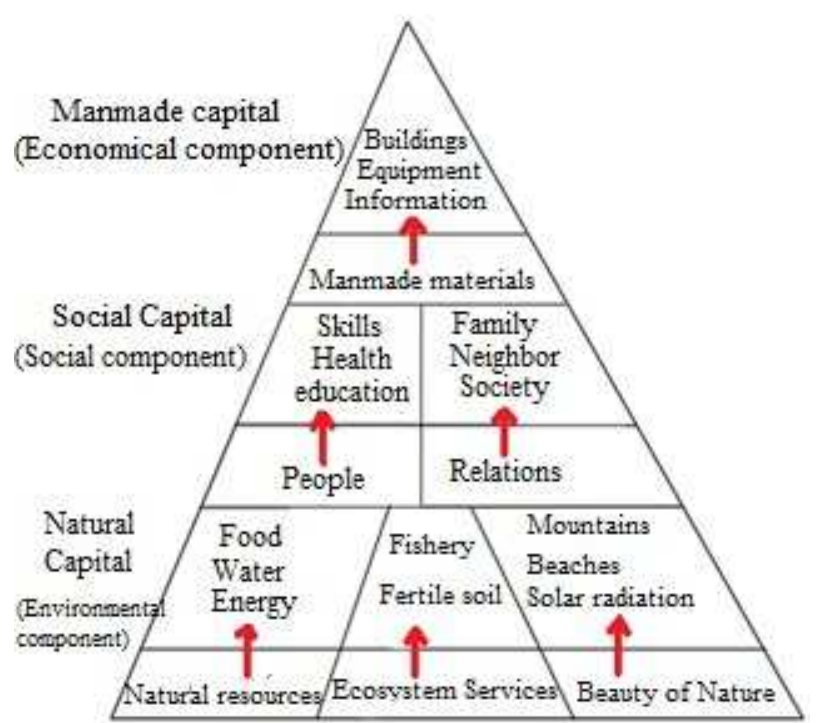

Figure 4. The existing capitals in a society

\subsection{The Conditions of Wealth in a Society}

The first research phase is finding the natural capitals, natural geographical situation, weather and climate, physiographic, the same as orbit, side, height, geology, earth, erosion, natural hazards, plant spore, plant and zoology spices, geopolitical conditions, distribution of cities and villages, respectively living points, changing population, estimating the population, population density, changing educated people, activity, jobless, distribution of the jobs depend on divisions of original economy and gathering elements information, and process of human building. Dividing the economy source, quality and respectively ranging and original plan for ways preparing energy and necessary source, education services, cultural, healthy and trading, telecommunication tourist culture and etc (Faryadi, 2011). To studying each group of the above elements, the original fifth programs for developing the country and beneficial and effective groups in the quality of the environment should be determined.

Table 1. SWOT for Jam Abroud vill

\section{Weaknesses}

$\mathrm{W}_{1}$ : lack of water and pollution of existing water resources

$\mathrm{W}_{2}$ :management of surface water resources out of the vill

$\mathrm{W}_{3}$ : atonal population growth and no proper distribution of general services

$\mathrm{W}_{4}$ : lack of health and educational facilities

$\mathrm{W}_{5}$ : increasing virtual jobs

$\mathrm{W}_{6}$ : low quality of roads inside the vill

$\mathrm{W}_{7}$ : lack of industrial investments in the vill

$\mathrm{W}_{8}$ : environmental degradation and increasing pollution

WO strategies (preservative pattern)

$\mathrm{WO}_{1}$ : Protection and development of water resources quality and exploitation of these existing resources

$\mathrm{WO}_{2}$ : Provision of employment opportunity

$\mathrm{WO}_{3}$ : Development of green space, control and reduction of environmental pollutions

$\mathrm{WO}_{4}$ : Improvement of natural landscape in the vill

\section{WT strategy (Defensive pattern)}

$\mathrm{WT}_{1}$ : Control of population growth and prevent population concentration

$\mathrm{WT}_{2}$ : Protection of arid and agricultural lands, forest and natural and virgin areas

$\mathrm{WT}_{3}$ : Sound management of soil resources to prevent of soil erosion and pollution

$\mathrm{WT}_{4}$ : Minimize damages caused by natural disasters

$\mathrm{WT}_{5}$ :Establishment of infrastructures and necessary equipments in the villages

\begin{abstract}
Strengths
$\mathrm{S}_{1}$ : Existence of holly place and historical areas and proper climate for tourism and recreational activities

$\mathrm{S}_{2}$ : Young population and educated people in the vill

$\mathrm{S}_{3}$ : existence of sand and silt in the vill

$\mathrm{S}_{4}$ : existence of fundamental infrastructures and easy access to Tehran

$\mathrm{S}_{5}$ : Existence of arable lands for different uses (agriculture, foresting, recreation, ...)

$\mathrm{S}_{6}$ : flowing of river in the vill

$\mathrm{S}_{7}$ : presence of police and security guards in the vill
\end{abstract}

\section{SO strategies (Offensive pattern)}

$\mathrm{SO}_{1}$ : development and strengthening tourism industry and recreational activities in the vill

$\mathrm{SO}_{2}$ : Fundraising from private and governmental sectors to establish industries in the vill

$\mathrm{SO}_{3}$ : increase and develop health, education and other services

\section{ST strategies (competitive pattern)}

$\mathrm{ST}_{1}$ : Agricultural development base on reduction of water use

$\mathrm{ST}_{2}$ : Use of surface water resources (river) for different uses in the vill

$\mathrm{ST}_{3}$ : Power assessment for industries establishment, new settlements,

$\mathrm{ST}_{4}$ : Use of educated local residents in directorate position in the vill

$\mathrm{ST}_{5}$ : Provision of security and peace in the vill

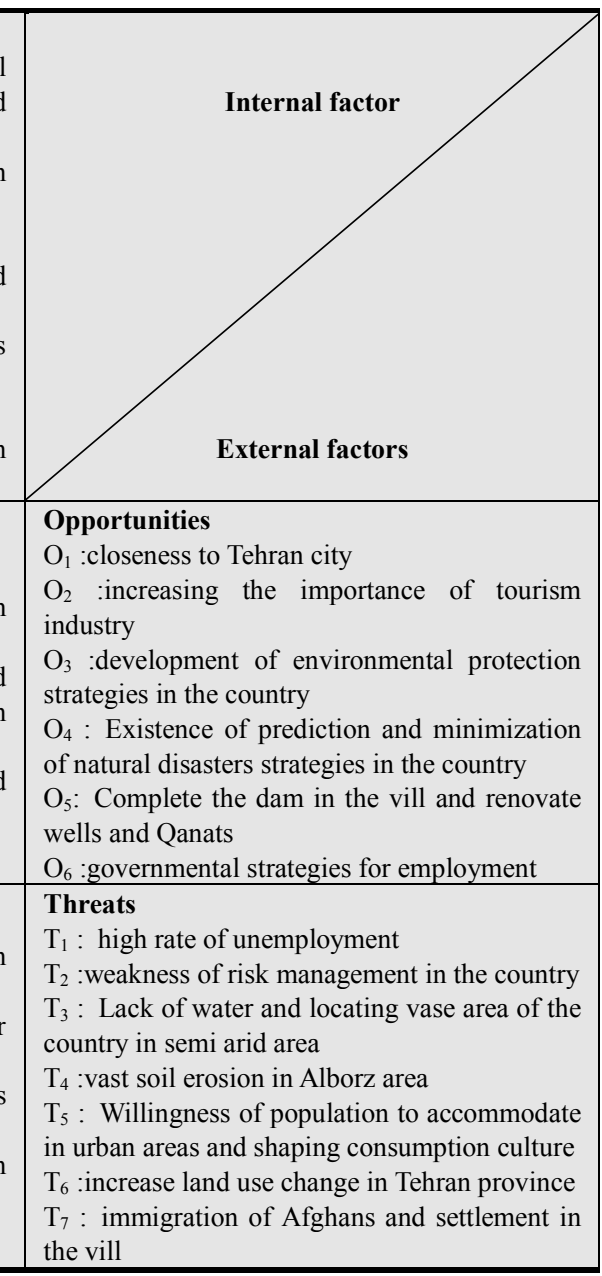

Reference: authors

For sustainable development it needs some methods and new techniques, that it be able to find the necessary rules, with their connection should be defined (Golusin et al, 2011).
In early years, different method of strategies for sustainable developing has been presented (Mokhtarshahi sani, 2011), at this study from combination analysis SWOT, and Analytic 
Network process method for rebuilding sustainable development strategies was used after investigating different conditions of existing parameters of Natural and humanity and society. In the Jamabroud village, the parameters that were connected to foreign actions or internal which was for strength or weakness of village development was extracted in the frame puzzle SWOT (Table 1) and after that developmental strategies was written (Table 1).

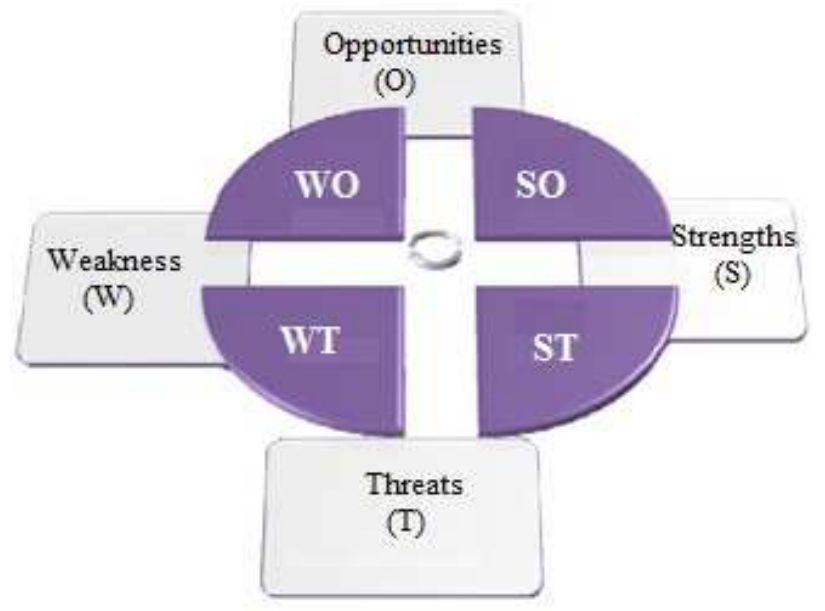

Figure 5. SWOT Four dimensions of analysis (Pierce \& Robinson, 1380؛ Golkar, 1385)

Those four large strategies for making sustainable development in the village are discussed as follows. The concept of SO strategy is using suitable chances with benefiting from strength points of the village. WO strategy is benefiting from suitable area with attentive to village weakness. ST strategy is also in connection to reducing or omitting hazardous effects by using benefits from strength points of the village. In addition, in the final WT strategy with pointing to weakness points of village, the hazardous results on environment is decreasing.

Because the resources always are limit and from the other side, the strategy create comparative advantage, and it have this strength to consume the resources for reaching to aims, the manager and planners trying to select those strategies that have most benefits (Fard, 2011), (Amalnic et al, 2010). At this research for grading and electing the best strategies Analytic Network Process (ANP), that is one of the best method for deciding multi-criteria, is used.

Analytic Network Process(ANP):Tomas in the years 1990 offered method for determining multi rate, that this was named Analytic Network process method, after many years ANP method was usual and multi purposes that is used solving the problems, Analytic Network process method makes a large frame that it is connected to theirs elements. (Saaty,1996), the results it with real world and people decision is more complicated (Saaty,2005), in the Analytic Network process method there is complicated relation between the original elements that is from substituting respective building with network construction (Zabardast, 2008) (Nabi Bidhendi et al, 2013).
This model is developed to improve the lack of connection between the elements and criteria in the hierarchy models (Banar et al, 2007). ANP is categorized to two sections: 1) the criteria and sub-criteria of the hierarchy models or the controlling network which control the transactions and, 2) a network including the effectiveness of clusters and elements.

To run the ANP model in this article, first the problem is seen due to ANP model which is including four levels. The first level is known as the goal (selecting the best scenario), the second level is the main criteria of SWOT model and the sub-criteria are in the third level. Moreover, the scenarios are presented in the fourth level (Figure 6).

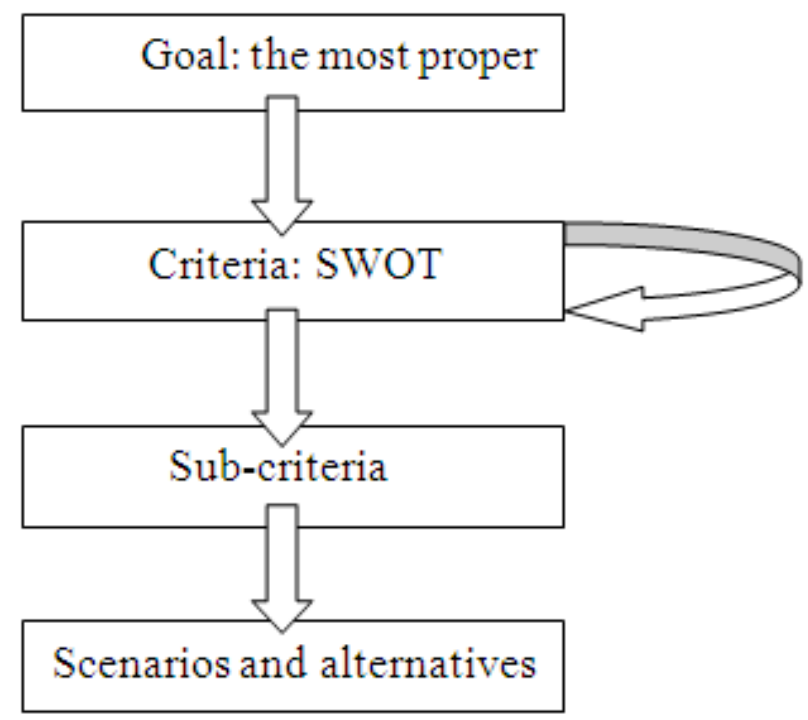

Figure 6. The hierarchy of the ANP model

After selecting the hierarchy of the model, connections and the dependency among the criteria and the pair-wise comparisons were assessed by the experts. However, the Saati's comparison model was chosen (Table 2).

Table 2. The Saati's pair-wise comparison model

\begin{tabular}{lc}
\hline Linguistic variables & Numbers \\
\hline Equal & 1 \\
Interval & 2 \\
Moderate & 3 \\
Interval & 4 \\
Strong & 5 \\
Interval & 6 \\
Very strong & 7 \\
Interval & 8 \\
Extreme & 9 \\
\hline
\end{tabular}

The pair-wise matrix of the main factors is given in Table 3. 
Table 3. Pair-wise comparison of the main factors

\begin{tabular}{ccccc}
\hline Factors & $\mathbf{S}$ & $\mathbf{W}$ & $\mathbf{O}$ & $\mathbf{T}$ \\
\hline $\mathrm{S}$ & 1 & 2 & 2 & 3 \\
$\mathrm{~W}$ & $1 / 2$ & 1 & 2 & 3 \\
$\mathrm{O}$ & $1 / 2$ & $1 / 2$ & 1 & 3 \\
$\mathrm{~T}$ & $1 / 3$ & $1 / 3$ & $1 / 3$ & 1 \\
\hline
\end{tabular}

After that, the dependencies among the main criteria due to their effects on each other which the assessing process is shown in Figure 7.

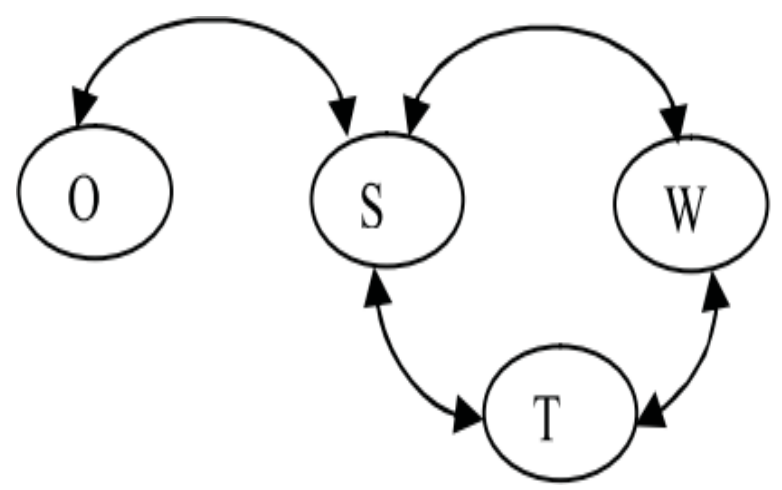

Figure7. Dependencies among the SWOT's main criteria

After that, due to Table 4, 5 and 6 the pair-wise comparisons are conducted. It should be mentioned that the opportunities are effects just by the strengths which leads not to have any matrices of the opportunities.

Table 4. Comparison matrix due to the strength

\begin{tabular}{cccc}
\hline (S) & W & O & T \\
\hline $\mathrm{W}$ & 1 & $1 / 7$ & $1 / 4$ \\
$\mathrm{O}$ & 7 & 1 & 3 \\
$\mathrm{~T}$ & 4 & $1 / 3$ & 1 \\
\hline
\end{tabular}

Table 5. Comparison matrix due to the weakness

\begin{tabular}{ccc}
\hline$(\mathbf{W})$ & $\mathbf{S}$ & $\mathbf{T}$ \\
\hline $\mathrm{S}$ & 1 & 7 \\
$\mathrm{~T}$ & $1 / 7$ & 1 \\
\hline
\end{tabular}

Table 6. Comparison matrix due to the threats

\begin{tabular}{ccc}
\hline (T) & S & W \\
\hline S & 1 & 6 \\
W & $1 / 6$ & 1 \\
\hline
\end{tabular}

In addition, the sub-criteria are compared to each other and the results are used in the Super Decision Software. This software was developed by the ANP group were employed in decision organization (Momeni and Sharifi Salim, 2011) (Nabi Bidhendi et al, 2013). The conducted model in the software is shown in Figure 8 and the results are given at Table7.

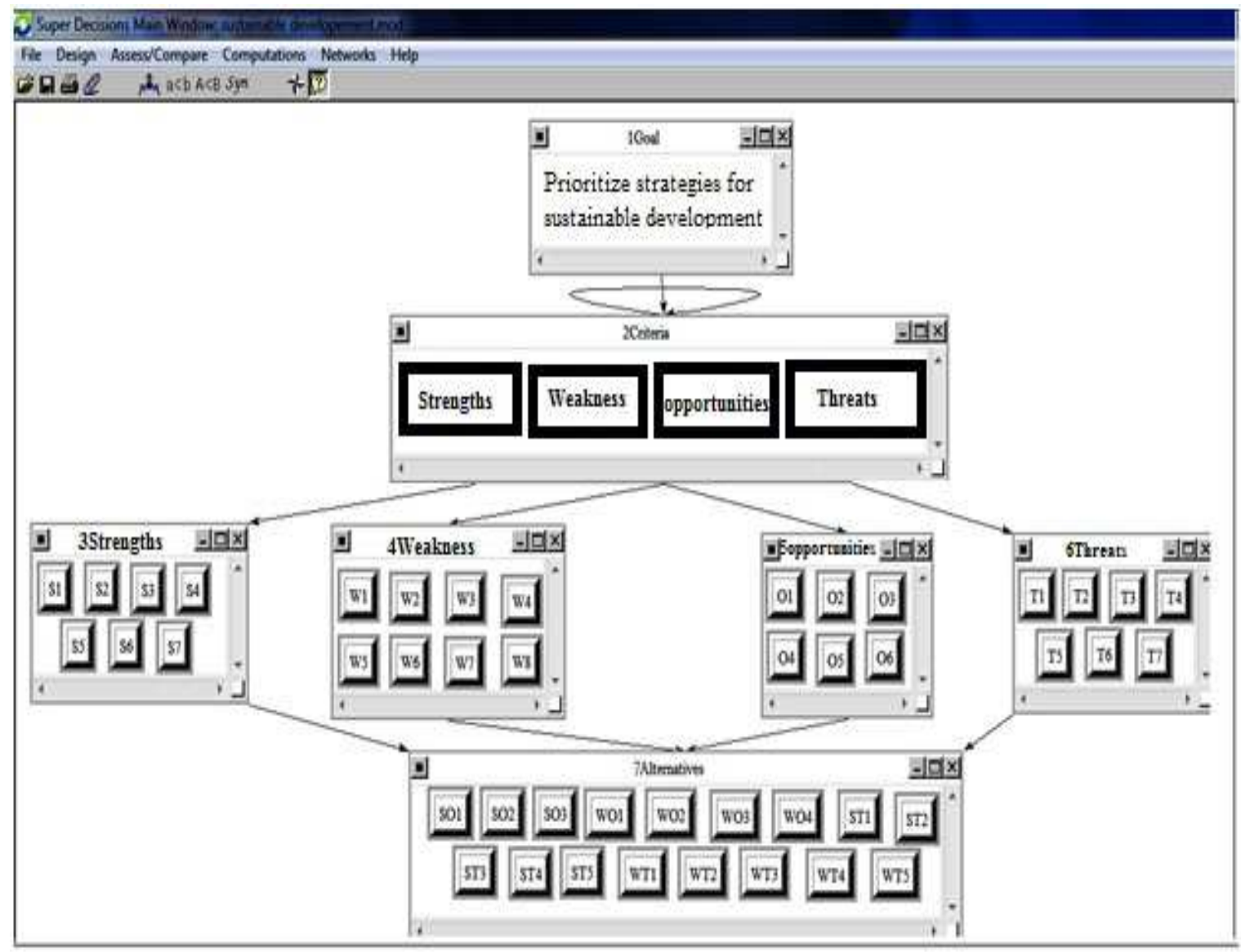

Figure 8. Network design strategies for sustainable development priorities in the software Super decision(Source: authors) 
Table 7. Final result of prioritization of strategies, executive plan and time schedule (Source: authors)

\begin{tabular}{|c|c|c|c|c|c|}
\hline Strategy & $\begin{array}{c}\text { Final } \\
\text { weight }\end{array}$ & Priority & Executive plan & Time & $\begin{array}{c}\text { Responsible organization } \\
\text { (Absard city) }\end{array}$ \\
\hline $\begin{array}{l}\mathrm{SO}_{1} \text { :development and } \\
\text { improvement of tourism } \\
\text { industry in the rural district }\end{array}$ & 0.164 & 1 & $\begin{array}{l}\text { Facilitating access to historical, religious and } \\
\text { recreational areas } \\
\text { Site selection and specifying areas for } \\
\text { citizens and tourisms } \\
\text { (Jam Abroud hosts citizens from Tehran in } \\
\text { different seasons) }\end{array}$ & $\begin{array}{l}\text { Short term } \\
\text { Short term }\end{array}$ & $\begin{array}{l}\text { Cultural heritage } \\
\text { organization, ... } \\
\text { Government, } \\
\text { Municipality, ... }\end{array}$ \\
\hline $\begin{array}{l}\mathrm{SO}_{2} \text { :fundraising for } \\
\text { establishment of industries } \\
\text { in the rural district }\end{array}$ & 0.112 & 2 & $\begin{array}{l}\text { Support private investors } \\
\text { Facilitating investments in the rural district } \\
\text { to establish early output institutions } \\
\text { Use of governmental budgets for } \\
\text { governmental related industries } \\
\text { establishment }\end{array}$ & $\begin{array}{l}\text { Long term } \\
\text { Short term } \\
\text { Medium term }\end{array}$ & $\begin{array}{l}\text { Governmental sector } \\
\text { Governmental sector } \\
\text { Governmental sector }\end{array}$ \\
\hline $\begin{array}{l}\mathrm{SO}_{3} 1 \text { :improvement of the } \\
\text { level of hygiene, education, } \\
\text { sport, ... }\end{array}$ & 0.078 & 5 & $\begin{array}{l}\text { Establishment of health care centers, } \\
\text { technical schools, library, sport hall, } \\
\text { Free and Payam-e-Noor university, } \\
\text { completion of hospitals }\end{array}$ & $\begin{array}{l}\text { Short term } \\
\text { Medium term } \\
\text { Medium term }\end{array}$ & $\begin{array}{l}\text { Governmental sector } \\
\text { Free university and } \\
\text { governmental sector }\end{array}$ \\
\hline $\begin{array}{l}\mathrm{WO}_{1} \quad \text { protection and } \\
\text { improvement of the quality } \\
\text { of existing water resources } \\
\text { and their exploitation }\end{array}$ & 0.092 & 3 & $\begin{array}{l}\text { Completion of Nime Kaveh Vadan dam } \\
\text { Increasing the depth of existing wells and } \\
\text { reuse of them, maintenance of exiting } \\
\text { Qanats }\end{array}$ & $\begin{array}{l}\text { Medium term } \\
\text { Short term }\end{array}$ & $\begin{array}{l}\text { Water and wastewater co. } \\
\text { Water and wastewater co. }\end{array}$ \\
\hline $\begin{array}{l}\mathrm{WO}_{2} \text { :providing job } \\
\text { opportunities } \\
\text { improvement the level of } \\
\text { employment }\end{array}$ & 0.069 & 6 & $\begin{array}{l}\text { Establishment of small industries with early } \\
\text { revenue } \\
\text { Establishment of conversion industries } \\
\text { (small packaging plants) beside the farms }\end{array}$ & $\begin{array}{l}\text { Short term } \\
\text { Short term }\end{array}$ & $\begin{array}{l}\text { Governmental and private } \\
\text { sector } \\
\text { Governmental and private } \\
\text { sector }\end{array}$ \\
\hline $\begin{array}{l}\mathrm{WO}_{3} \text { :development of green } \\
\text { space, control and } \\
\text { prevention of environmental } \\
\text { pollution }\end{array}$ & 0.043 & 9 & $\begin{array}{l}\text { Establishment of green belt surrounding the } \\
\text { industrial and mining zones and silt and sand } \\
\text { factories } \\
\text { Rural and urban waste management } \\
\text { Urban and industrial waste water } \\
\text { management }\end{array}$ & $\begin{array}{l}\text { Short term } \\
\text { Short term } \\
\text { Short term }\end{array}$ & $\begin{array}{l}\text { Industries } \\
\text { Municipality } \\
\text { Water and wastewater co. }\end{array}$ \\
\hline $\begin{array}{l}\mathrm{WO}_{4} \text { :improvement of } \\
\text { natural landscape in the rural } \\
\text { district }\end{array}$ & 0.016 & 15 & $\begin{array}{l}\text { Establishment of parks and landscapes in } \\
\text { and surrounding of the cities (Absard and } \\
\text { Kilan) } \\
\text { Design and management of existing natural } \\
\text { recreational areas }\end{array}$ & $\begin{array}{l}\text { Medium term } \\
\text { Short term }\end{array}$ & $\begin{array}{l}\text { Municipality } \\
\text { Department of Environment }\end{array}$ \\
\hline $\begin{array}{l}\mathrm{ST}_{1} \text { :agricultural } \\
\text { development based on } \\
\text { reduction of water use }\end{array}$ & 0.088 & 4 & $\begin{array}{l}\text { Establishment of green houses for } \\
\text { vegetables, development of dry land farming } \\
\text { Application of farming practices that rely on } \\
\text { rain fall in rain-fed farming }\end{array}$ & $\begin{array}{l}\text { Medium term } \\
\text { Short term }\end{array}$ & $\begin{array}{l}\text { Agricultural office } \\
\text { Agricultural office }\end{array}$ \\
\hline $\begin{array}{l}\mathrm{ST}_{2} \text { :use of surface waters } \\
\text { (rivers) for different } \\
\text { application in the rural } \\
\text { district }\end{array}$ & 0.043 & 9 & $\begin{array}{l}\text { Construction of dams on the surface water } \\
\text { flow } \\
\text { Transmission of surface waters to arable } \\
\text { lands }\end{array}$ & $\begin{array}{l}\text { Medium term } \\
\text { Medium term }\end{array}$ & $\begin{array}{l}\text { Water and wastewater co. } \\
\text {, Jihad-e-Agriculture } \\
\text { Water and wastewater co. }\end{array}$ \\
\hline $\begin{array}{l}\mathrm{ST}_{3} \text { :feasibility study for } \\
\text { establishment of industries, } \\
\text { dwellings, ... }\end{array}$ & 0.066 & 7 & $\begin{array}{l}\text { Site selection for new residential complexes } \\
\text { Site selection for industrial complexes } \\
\text { Use of arable lands for agricultural } \\
\text { development,... }\end{array}$ & $\begin{array}{l}\text { Short term } \\
\text { Short term } \\
\text { Short term }\end{array}$ & $\begin{array}{l}\text { Housing Foundation } \\
\text { Municipality } \\
\text { Jihad-e-Agriculture }\end{array}$ \\
\hline $\begin{array}{l}\mathrm{ST}_{4} \text { :use of educated } \\
\text { endemical human resources } \\
\text { in managerial position in the } \\
\text { rural district }\end{array}$ & 0.032 & 13 & $\begin{array}{l}\text { Provision of intensive methods to persuade } \\
\text { endemic professionals to come back to the } \\
\text { rural district } \\
\text { Improving the literacy level and training } \\
\text { endemic human resources in the rural district }\end{array}$ & $\begin{array}{l}\text { Medium term } \\
\text { Long term }\end{array}$ & $\begin{array}{l}\text { Governmental sector } \\
\text { Governmental sector }\end{array}$ \\
\hline $\begin{array}{l}\mathrm{ST}_{5} \text { :provision of peace and } \\
\text { safety in the rural district }\end{array}$ & 0.022 & 14 & $\begin{array}{l}\text { Settlement of Afghan immigrants in camps } \\
\text { and control them } \\
\text { Provision of safety specially in tourism areas }\end{array}$ & $\begin{array}{l}\text { Long term } \\
\text { Short term }\end{array}$ & $\begin{array}{l}\text { Government and police } \\
\text { centers } \\
\text { police centers }\end{array}$ \\
\hline $\begin{array}{l}\mathrm{WT}_{1} \text { :control of population } \\
\text { growth and prevention of } \\
\text { population concentration }\end{array}$ & 0.033 & 12 & $\begin{array}{l}\text { Training of the families to prevent } \\
\text { population growth } \\
\text { Fair distribution of services and equipments } \\
\text { in cities and villages to prevent immigration } \\
\text { of rural population to urban areas }\end{array}$ & $\begin{array}{l}\text { Long term } \\
\text { Long term }\end{array}$ & $\begin{array}{l}\text { Educational centers } \\
\text { Governmental sector }\end{array}$ \\
\hline $\begin{array}{l}\mathrm{WT}_{2} \text { :protection of arid, } \\
\text { agricultural, forests and } \\
\text { virgin and natural lands }\end{array}$ & 0.047 & 8 & $\begin{array}{l}\text { Implementation of legal forces to prevent the } \\
\text { area destruction } \\
\text { Prevention of changing the range lands to } \\
\text { agricultural lands }\end{array}$ & $\begin{array}{l}\text { Long term } \\
\text { Short term }\end{array}$ & $\begin{array}{l}\text { Governmental sector } \\
\text { Forest, range and watershed }\end{array}$ \\
\hline
\end{tabular}




\begin{tabular}{|c|c|c|c|c|c|}
\hline Strategy & $\begin{array}{c}\text { Final } \\
\text { weight }\end{array}$ & Priority & Executive plan & Time & $\begin{array}{c}\text { Responsible organization } \\
\text { (Absard city) }\end{array}$ \\
\hline $\begin{array}{l}\mathrm{WT}_{3} \text { :sound management of } \\
\text { soil resources to preventing } \\
\text { the erosion and pollution }\end{array}$ & 0.015 & 16 & $\begin{array}{l}\text { Training farming by ecological methods } \\
\text { Keeping proper drainage for gathering } \\
\text { agricultural run off }\end{array}$ & $\begin{array}{l}\text { Short term } \\
\text { Short term }\end{array}$ & $\begin{array}{l}\text { Jihad-e-Agriculture } \\
\text { Jihad-e-Agriculture }\end{array}$ \\
\hline $\begin{array}{l}\mathrm{WT}_{4} \text { :minimization of } \\
\text { damages caused by natural } \\
\text { disasters }\end{array}$ & 0.038 & 11 & $\begin{array}{l}\text { Implementation of the regulations on } \\
\text { earthquake resistant design of buildings } \\
\text { Planting in the border of river, } \\
\text { establishment of flood barriers }\end{array}$ & $\begin{array}{l}\text { Short term } \\
\text { Medium term }\end{array}$ & $\begin{array}{l}\text { Housing Foundation } \\
\text { Governmental sector }\end{array}$ \\
\hline $\begin{array}{l}\mathrm{WT}_{5} \text { :provision of necessary } \\
\text { infrastructures and } \\
\text { equipments in the provinces }\end{array}$ & 0.042 & 10 & $\begin{array}{l}\text { Establishment of primary schools, health } \\
\text { care centers, mosques, provision of drinking } \\
\text { water } \\
\text { Completion of gas pipe installation for } \\
\text { villages in the rural district }\end{array}$ & $\begin{array}{l}\text { Short term } \\
\text { Medium term }\end{array}$ & $\begin{array}{l}\text { Governmental sector } \\
\text { Gas office }\end{array}$ \\
\hline
\end{tabular}

\section{Result and Discussion}

However, due to the Table 7 the scenario of "developing the tourism industry" is chosen as the most proper scenario than the others. Moreover, the invasive patterns have more weights which the conservative, competitive and defensive patterns are founded as the next strategies. It should be mentioned that the combination of these strategies causes the sustainable development. Hence, the practical solutions due to the responsible organs, time period and location are presented at Table 7. In addition, based on the small study area (jamAbroud) the horizon of the project is 10 years and the short time period explanation refers to two years period, medium refers to five years and long time period leads to 10 years.

\section{Conclusions}

By attention to the importance original factors SWOT in respectively, the strategies are different. So the weight original SWOT factors should be noticed, but SWOT matrix is not able to weigh these rates that is depends on different strategies affect. Many studies have been done in this area. Some studies by using AHP method that is only for respective connective and equal relation. At this study from Analytic Network process method for solving this problem is used.

In SWOT matrix, patterns and strategies are defined base on 4 criteria of strengths, Weaknesses, Opportunities and Threats. Since the importance of the main factors of SWOT is different for prioritization of strategies, therefore the main factor should be weighted. However SWOT Matrix is not able to determine the effects of the weight of these criteria on different strategies. Lots of studies and researches is done and most of them are focused on determination of the importance of the factors and weighting them by definite numbers and dependency of factors, sub factors and options are not considered. Further, some studies were done by applying AHP method which just consider hierarchy relations of factors and not same-level and reciprocal relations.

In this study Analytic Network Process were applied to solve this problem. Analytic Network Process will cause that the hypothesis of dependency of factors, sub factors and options in hierarchy structure and dependency of semi level factors and mutual dependency among the criteria are considered. In the proposed method, the first level is selecting the best strategy and other levels are SWOT factors, SWOT sub factors, and different strategies which are considered within SWOT factors in strengths, weaknesses, opportunities and threats points.

After constructing the structure, to determine the relative weight of the factors, sub factors and alternatives in decision making matrixes, pair wise comparisons and Super Decision methods were applied. The result of applying these methods reveals that the best alternative is "development and strengthening of tourism industry and recreational activities in the country" which is selected from SO strategies (offensive pattern). The proposed method is capable for development and improvement. It's proposed, this method will be studied by considering the effects of relations between sub criteria, and interrelations in sub criteria and strategies level. Also Fuzzy methods could be applied to eliminate the defects use of expert ideas in pair wise comparisons.

\section{References}

[1] M. Banar, B.M. Kose, A. Ozkan and I.P. Acar, choosing a municipal landfill site by analytic network process, Environ Geol journal, Vol. 52, Pp:747-751. 2007.

[2] A.A. Enayati, FAQ and methodology of sustainable development indicators, Secretariat of the National Committee on Sustainable Development, Tehran. 2007, http:/www./irandoe.org/doeportal/ncsd

[3] SH. Faryadi, Regional Planning Services. Faculty of Environment. Tehran University.Pp 2-3, 2011.

[4] R.D. Fered, Strategic Management, 19th Edition, Publications Office of Cultural Research, Tehran. 2011.

[5] M. Gharakhloo, S.H Hoseini, Indicators for sustainable urban development, Journal of Geography and Regional Development, No 8, Page 157-177, 2005.

[6] S.H. Ghodsipoor, Hierarchical analysis of process, Fifth Edition, Amirkabir University Press, pp 220, Tehran. 2007.

[7] K. Golkar, Analytical techniques, the majority of travelers «SWOT» for application in urban design, Journal Safeh, No 41, Pp 2-21. .2005. 
[8] Z. Golshiri Esfahani and M.H Saraee, Villages with SWOT analysis and strategic planning of environmental, Rural Research,No 4.Page 73-98. 2010

[9] M. Golusin, O.M. Ivanovic and N. Teodorovic, The review of the achieved degree of sustainable development in South Eastern Europe - the use of linear regression method, Renewable and Sustainable Energy Reviews, Vol. 15, Pp: 766-772, 2011

[10] E. Hanff, M.H. Dabat and J. Blin, Are biofuels an efficient technology for generating sustainable development in oil-dependent African nations? A macroeconomic assessment of the opportunities and impacts in Burkina Faso, Renewable and Sustainable Energy Reviews, Vol. 15, Pp: 2199-2209. 2011.

[11] Hart. The capital of a society, p16, 1995. available at: http://www.hku.hk/sdindic.

[12] C. Karakosta, and A. Dimitris, Developing countries' energy needs and priorities under a sustainable development perspective: A linguistic decision support approach, Energy for Sustainable Development, Vol. 14, Pp: 330-338, 2010.

[13] C. Karakosta, H. Doukas and J. Psarras. Directing clean development mechanism towards developing countries' sustainable development priorities, Energy for Sustainable Development, Vol. 13, Pp: 77-84. 2009.

[14] S.A. Khatoonabadi, Aspects of sustainable development (From thought to action), Jahad University Unit of Technology Esfahan,Esfahan, Management, 2006.

[15] Y. Lui, D. He, S. Buchanan. and J. Liu, Ecological Footprint Dynamic Of Yunnan China. Journal Of Mountain Science. Vol. 6, No. 3, Pp: 286-292, 2009.

[16] R. Mokhtarshahi Sani, and P. Mahasti, Regenerating Regional Identity for Sustainable Tourism Development Case Study: Eslami Island Iran, Asia Pacific International Conference on Environment-Behaviour Studies, Salamis Bay Conti Resort Hotel, Famagusta, North Cyprus, 7-9 December 2011, Procedia - Social and Behavioral Sciences, Vol. 35, Pp:523 - 530. 2011

[17] M. Momeni, A. Sharifi Salim, Models and multi-criteria decision making applications, First Printing, Publisher authors Sponsored by Elixir Pharmaceuticals Inc.,218 Page. Tehran, Iran. 2011.

[18] K. Mori and A. Christodulou, Review Of Sustainability Incidences and Indicators: Towards A New City Sustainability Index (CSI). Journal of Environmental Impact Assessment Review. Pp 1-13. 2011.
[19] GH. Nabi Bidhendi, M.J. Amiri, Sh. Karami, Application of multi-criteria decision-making methods in environment, Kiajor publication, 120page, Tehran, Iran. 2013.

[20] D. Olj, M. Ivanovic, M.T. Golusiz, S.N. Dodic, and J.M. Dodic, Perspectives sustainable development in countries of Southeastern Europe, Renewable and Sustainable Energy Reviews, Vol. 13, Pp: 2079-2087. 2009.

[21] A. Pierce, R. Robinson, translated to Persian by S. khalili shorini, Planning and Strategic Management, Yadvareh ketab publication, Tehran. 2001.

[22] M.R. Poorjafar, Z. Khodaee, Geological indicators of sustainable urban development, National Conference on Contemporary Iranian Architecture and Urbanism, 15 pages, Beyza, 2010.

[23] Portal Department of the Interior, 2012 portal2. moi.ir

[24] M. Rafieeyan, N. Yabrekpoor, M. Roknapoor, Metropolitan areas of development strategies of Sustainable Development (Model based on SEA) Case study: Tehran Urban Complex Plan, Journal of Urban Management, no 19, Pp: 7-18, 2007.

[25] T.L. Saaty, Theory and Applications of the Analytic Network Process, RWS Publications, Pittsburgh, 2005.

[26] T.L. Saaty, Decision Making with Dependence and Feedback the Analytic Network Process. RWS Publications, Pittsburgh, 1996.

[27] S. amal nick, A. Ansari nezhad, S. ansari nezhad, and S. Miri Nargesi, By causality relationships and rank critical success factors and failure of information systems to help implement projects combined ANP and DEMATEL, fuzzy group method, Journal of Industrial Engineering, Volume 44, No 2, Page 195-212. 2010.

[28] Site Statistics Agency, Census 2011. 2012. Www. amar.org.ir

[29] H. Weihrich, The TOWS Matrix: A Tool for Situational Analysis, Long Range Planning, Vol. 15(2), Pp: 54-66, 1982.

[30] A. Zebardast, Application of network analysis in urban and regional planning process, Tehran, Journal of Art, Architecture and Urbanism. No 41, Pp: 79-90, 2009.

[31] M. Ziaee, R. Mohamad Alipoor, Sustainable Development Indicators, Evaluate tourism projects, Allameh Tabatabai University, 2007. Www. tourismscience.ir 